PF 2020 (75/1): 501-516

https://doi.org/10.32798/pf.674

\author{
MARIOLA WOŁK \\ Katedra Języka Polskiego \\ Uniwersytet Warmińsko-Mazurski, Olsztyn \\ e-mail: mariola.wolk@uwm.edu.pl \\ ORCID 0000-0002-4529-1644
}

\title{
O KIMŚ INNYM. STATUS I SPECYFIKA PEWNEGO TYPU WYKŁADNIKÓW REFERENCJI W JĘZYKU POLSKIM
}

\section{ABOUT KTOŚ INNY. THE STATUS AND NATURE OF A CERTAIN TYPE OF REFERENCE INDICATORS IN POLISH}

\begin{abstract}
The study focuses on a series of expressions containing the adjective inny [other / else] and a pronoun attached to it on the left side. Apart from the expression mentioned in the title [namely someone else], the set includes also nikt inny [no one else], żaden inny [no other], jakiś inny [some other], coś innego [something else], and nic innego [nothing else]. The aim of the analysis is thus to identify the status of these expressions, which at first glance belong to a homogeneous series. That is why it is essential to determine whether they are separate units of language (as understood by Andrzej Bogusławki (1976)), or whether they are regular compound expressions. The task requires considering each of the six expressions individually. In order to do that, it is necessary to apply a reduction test concerning the left-hand element. The next step is to assess whether the analysed expressions open or block their right valency position for a noun. Additionally, a substitution test referring to particular elements of the given expressions is applied. The article is an attempt at revising one of the hypotheses on the status of the analysed expressions, which were rather hastily proposed by the author at an earlier stage.
\end{abstract}

KEYWORDS: other / else, linguistic unit, semantics, adjective, valency position

SŁOWA KLUCZOWE: inny, jednostka języka, semantyka, przymiotnik, pozycja walencyjna 
1. W niniejszym artykule chciałabym odnieść się do dość śmiałej hipotezy, którą zbyt pochopnie wysunęłam w swoim tekście na temat przymiotnika inny i przymiotników podobnych znaczeniowo (por. Wołk 2019). Dotyczyła ona w zasadzie serii wyrażeń zbudowanych z przymiotnika inny i lewostronnie dostawionego do niego zaimka. Obok tytułowego wyrażenia do tej klasy należą takie ciągi, jak np. nikt inny, żaden inny, jakiś inny, coś innego, nic innego. W swoich ustaleniach sprowadziłam je do wspólnego mianownika i uznałam za jednostkę operacyjną o postaci_inny, mogącą podlegać regularnym przekształceniom, w wyniku których określony element ( $w$ tym wypadku lewostronny) zastępowany jest innym elementem, a forma fleksyjna, powiedzmy, bazowego elementu inny bywa pod wpływem takich substytucji dostosowywana do wymagań gramatycznych jego lewostronnego uzupełnienia, jak np. w wyrażeniu coś innego (por. Wołk 2019: 56). W samym pomyśle rozważenia możliwości takiego rozwiązania nie ma nic niewłaściwego, przeciwnie - jak pokazuje w swoich pracach Andrzej Bogusławski (por. np. Bogusławski, Wawrzyńczyk 1993) - pozwala ono na właściwe potraktowanie bytów językowych nie tyle faktycznie różnych od siebie, ile w jakimś sensie wariantywnych. Taka kategoria opisu stwarza więc też zaporę przed mnożeniem bytów ponad potrzebę, jednocześnie dając poręczne narzędzie techniczne, cenne szczególnie w charakterystyce dużej liczby wyrażeń. Na takie rozwiązanie można jednak przystać wówczas, gdy rozpatrywana grupa wyrażeń rzeczywiście różni się między sobą w sposób identyczny (Bogusławski, Wawrzyńczyk 1993, s. 16). Tymczasem odpowiednio uważny ogląd wymienionych wyżej ciągów bazujących na przymiotniku inny prowadzi do innych wniosków. Już w punkcie wyjścia uznaję zatem swoją wcześniejszą hipotezę za błędną. Celem tych rozważań będzie zastąpienie jej hipotezą lepszą, a tym samym ustalenie statusu wyrażeń składających się na to, co na pierwszy rzut oka wygląda na w miarę jednolitą serię. Sprawą podstawową będzie rozstrzygnięcie, czy są one odrębnymi jednostkami języka (w rozumieniu A. Bogusławskiego, por. np. Bogusławski 1976), czy regularnymi złożeniami. Dojście do takich ustaleń będzie wymagało indywidualnego potraktowania każdego z wyrażeń.

2. Do kwestii statusu jednego z przywołanych wyżej ciągów odniosła się w Składni grupy imiennej Zuzanna Topolińska (1984). W wymienionym opracowaniu znajduje się niewielki, ale przynoszący konkretne ustalenia, fragment na temat wyrażenia jakiś inny. Autorka opisuje je w grupie wykładników referencji i oceny ilościowej, czyli jako element, który w przedstawionym przez nią podstawowym modelu syntaktycznym grupy imiennej stanowi tzw. segment I (Topolińska 1984, s. 367). Jego właściwa postać: (jakiś) inny x zdaje sprawę z podstawowych właściwości tego wyrażenia, czyli, po pierwsze, fakultatywności członu lewostronnego, po drugie, pozycji otwieranej prawostronnie przez przymiotnik dla rzeczownika. Z. Topolińska włącza rozpatrywane wyrażenie do złożonych operatorów (obok ciągów ci wszyscy i żaden $z$ nich) czy też ściślej: 
„operatorów «wyższego piętra» operujących na grupach już wyznaczonych, tj. tworzących łącznie z operatorami referencji podstawowej nowe operatory złożone" (Topolińska 1984, s. 372-373).

Funkcja dodatkowych operatorów sprowadza się według autorki do potwierdzenia - jak zaznacza, często ekspresywnego - zakresu odniesienia odpowiednich grup imiennych (Topolińska 1984, s. 373) ${ }^{1}$.

Przytoczone ustalenia wywołują pytanie o to, czy pozostałe wyrażenia z interesującej mnie grupy funkcjonują analogicznie. Dlatego w ich analizie pójdę torem, który zdaje się wyznaczać Topolińska. Podstawowym testem służącym do zbadania postawionego problemu, będzie test redukcji członu lewostronnego, który roboczo będę nazywała dodatkowym, w opozycji do przymiotnika inny, który również roboczo określę jako człon bazowy. Gdyby bowiem rzeczywiście było tak, jak przyjęłam wcześniej (Wołk 2019, s. 55-56), to każdy z członów dodatkowych w poszczególnych ciągach mógłby być redukowalny na takich samych zasadach. Drugą rzeczą, którą wezmę pod uwagę w badaniach, będzie kwestia otwierania vs. blokowania prawostronnej pozycji dla rzeczownika, która w wypadku opisywanych przeze mnie wyrażeń (inaczej niż w pracy Topolińskiej) nie jest oczywista.

\section{1. ktoś inny ${ }^{2}$}

Ciąg ktoś inny jako wyrażenie pełniące funkcję grupy imiennej charakteryzuje się blokadą prawostronnej pozycji dla rzeczownika (por. dewiacyjne: ${ }^{\star}$ Ktoś inny wariat wysyła te świństwa). Lewostronny element ktoś może podlegać redukcji, ale zasadniczo tylko w dwóch typach kontekstów. Pierwszą ich grupę stanowią wypowiedzenia, w których przymiotnik inny jest drugim członem konstrukcji paralelnej (typu ktoś, ktoś inny), jak w przykładach ${ }^{3}$ :

(1) Nieopodal ktoś okropnie bełkotał, ktoś inny kaszlał i stękał. / Nieopodal ktoś okropnie bełkotał, inny kaszlał i stękał.

(2) Ktoś komuś wydaje rozkazy, ktoś inny tłumaczy na rozkaz. / Ktoś komuś wydaje rozkazy, inny tłumaczy na rozkaz.

(3) Ktoś rzucił na arenę pogryzioną kiełbasę, ktoś inny but. / Ktoś rzucił na arenę pogryzioną kiełbasę, inny (rzucił) but.

Do charakterystyki wyrażenia (jakiś) inny wrócę w dalszej części rozważań (p. 2.2).

2 Postać ciągów pojawiających się w podtytułach do pp. 2.1-2.5 ma charakter czysto hipotetyczny i pełni wyłącznie funkcję roboczej etykietki. Rozważania podjęte w poszczególnych fragmentach służą m.in. jej zweryfikowaniu.

3 Materiał przykładowy pochodzi z NKJP. Spreparowane są zdania będące przedmiotem operacji testujących. 
(4) Ktoś przyjeżdżał, ktoś inny wyjeżdżał. / Ktoś przyjeżdżał, inny wyjeżdżał.

(5) Ktoś przeskoczył przeze mnie, ktoś inny zawadził o mnie nogą. / Ktoś przeskoczył przeze mnie, inny zawadził o mnie nogą.

(6) Ktoś zamachnął się, cisnął granat, ktoś inny siał seriami z pistoletu maszynowego. / Ktoś zamachnął się, cisnął granat, inny siał seriami z pistoletu maszynowego.

Do drugiej grupy należą konteksty, w których słowo inny może funkcjonować samodzielnie, tj. bez członu dodatkowego, ponieważ w wyniku substantywizacji przejmuje funkcję rzeczownika (podobnie jak np. wyrażenie chory w zdaniu Chory czuje się już lepiej) ${ }^{4}$, por. wybrane przykłady:

(7) Mogła wybrać kogoś innego, a wybrała takiego przeciętnego gostka jak ja. / Mogła wybrać innego, a wybrała takiego przeciętnego gostka jak ja.

(8) A może masz kogoś innego? / A może masz innego?

(9) Cóż, Eliszka, gdy się nie ma, co się lubi... Chodź, znajdziemy ci kogoś innego. / Cóż, Eliszka, gdy się nie ma, co się lubi... Chodź, znajdziemy ci innego.

(10) Nie może już dłużej ze mną być. - Ale ma kogoś innego ? - Tego nie wie nikt. Twierdzi, że nie ma. / Nie może już dłużej ze mną być. - Ale ma innego ? - Tego nie wie nikt. Twierdzi, że nie ma.

(11) Była młoda, mogła jeszcze uwolnić się od niego i znaleźć kogoś innego. / Była młoda, mogła jeszcze uwolnić się od niego i znaleźć innego.

Najczęściej spotykamy się z tego rodzaju (urzeczownikowionymi/zsubstantywizowanymi) użyciami wyrażenia inny w liczbie mnogiej, por. np. Inni już są, a mnie jeszcze nie ma, Żyj i daj żý innym. Słowo to funkcjonuje w takich kontekstach samodzielnie ( $\mathrm{tj}$. bez lewostronnego uzupełnienia), a pozycja członu dodatkowego jeśli jest wypełniana, to przez wykładniki referencji takie jak np. ci/te lub jacyś/jakieś (por. ci inni, te inne, jacyś inni, jakieś inne). Zakres jego odniesienia, poza oczywistym wskazaniem zbioru, nie podlega większym ograniczeniom. Inaczej jest z wyrażeniem ktoś inny redukowalnym do członu inny w funkcji rzeczownika - jego odniesienie zawęża się do osób będących czyimś partnerem. Zauważmy, że konteksty w rodzaju: ?Miała już innego do naprawy pralki, ?Dała klucze innemu - w przeciwieństwie do przykładów (7)-(11) z wyelidowanym członem lewostronnym - pozostają na granicy akceptowalności. Należałoby je włączyć do kolejnej i jednocześnie największej grupy kontekstów, które wchodzą w grę w przeprowadzanym badaniu.

Otóż, redukcja członu dodatkowego ktoś na dobrą sprawę jest możliwa niemal zawsze pod warunkiem, że zadziała system odesłania wstecz (anafora) w obrębie wypowiedzenia lub tekstu, czyli najpierw pojawia się rzeczownik (lub zaimek),

$4 \quad$ O substantywizacji zob. w: Jodłowski 1971. 
a dalej na linii tekstu znajduje się przymiotnik inny odnoszący się do wcześniejszego rzeczownika. Por. $\mathrm{np}^{5}$.:

(12) Zadzwonił w końcu fachowiec, którego prosiła o pomoc. Ale miała już innego do naprawy pralki.

(13) O klucze do gabinetu poprosił ją jeden z portierów. Nie mogła mu ich dać. Dała więc klucze innemu.

(14) To numer telefonu do tego lekarza. Jeżeli słuchawkę podniesie inny, zrozumie pan, że to pomyłka.

Jeśli natomiast układ wypowiedzenia wyklucza możliwość wystąpienia wyrażenia inny w funkcji anafory, redukcja zaimka ktoś jest niedopuszczalna. Zdania (15)-(17), funkcjonujące poza kontekstem jasno precyzującym odniesienie słowa inny, są nieakceptowalne, por.:

(15) *Pani na pewno przyszła do innego.

(16) ${ }^{\star}$ Czas przekazać to wszystko innemu.

(17) *Inny wysyła te świństwa.

Podsumowując, wyrażenie ktoś inny zasadniczo słabo funkcjonuje bez lewostronnego członu. Jego redukcja pod pewnymi warunkami jest możliwa, ale bezdyskusyjną akceptowalność gwarantuje jedynie użycie pełnej dwuczłonowej postaci wyrażenia. W związku z tym na obecnym etapie badań uznaję ciąg ktoś inny za pretendujący do roli jednostki języka.

\section{2. jakiś inny}

Wyrażenie jakiś inny występuje albo - jak zdaje z tego sprawę Z. Topolińska (1984) - jako składnik grupy imiennej otwierający z prawej strony pozycję dla rzeczownika ((jakiś) inny p) (por. niżej przykłady (18)-(21)), albo w funkcji orzecznika (ktoś / coś jest jakiś inny / jakieś inne) (por. niżej przykłady (22)-(25)). W obu pozycjach możliwa jest redukcja lewostronnego członu bez zauważalnej na pierwszy rzut oka, wyraźnej zmiany znaczenia zdania. Por.:

(18) Zagrał cichutko jakiś inny motyw / Zagrał cichutko inny motyw.

(19) Może lepiej było kupić jakiś inny samolot / Może lepiej było kupić inny samolot

5 Ze względu na konieczny w rozważanym przypadku lewostronny kontekst przykłady (12)-(14) zostały przeze mnie odpowiednio zmodyfikowane (głównie poprzez lewostronne uzupełnienie). Oczywiście poza kontekstem tych rozważań wyrażenie inny z przytoczonych układów można byłoby interpretować także inaczej: jako frazę z wyelidowanym rzeczownikiem z pierwszego zdania w sekwencji. 
(20) On ma jakiś inny adres mailowy? / On ma inny adres mailowy?

(21) Krył się za tym jakiś inny powód / Krył się za tym inny powód.

(22) Anna miała wrażenie, że jest jakiś inny, mniej spięty / Anna miała wrażenie, że jest inny, mniej spięty

(23) Ta samotność jest jakaś inna niż te, które przeżywała do tej pory / Ta samotność jest inna niż te, które przeżywała do tej pory

(24) Zaczęłam po śniadaniu, gdy spostrzegłam, że ona jest jakaś inna, jakby się czymś dręczyła / Zaczęłam po śniadaniu, gdy spostrzegłam, że ona jest inna, jakby się czymś dręczyła.

(25) Oczywiście zauważyła, że mu się podoba, zauważyła też, że jest jakiś inny niż tamten, którego pożegnała latem trzydziestego szóstego roku / (...) zauważyła też, że jest inny niż tamten, którego pożegnała latem trzydziestego szóstego roku

Rozpatrywany ciąg z przykładów (22)-(25) ma w istocie postać ktoś / coś jest jakiś inny / jakieś inne niż, pełni zatem funkcję wyrażenia predykatywnego, a nie wykładnika referencji. Z tego powodu pozostaje poza zakresem badanego zagadnienia. Jeśli zaś chodzi o wyrażenie jakiś inny p ze zdań (18)-(21), to lewostronny człon wpływa jednak na wartość informacyjną wypowiedzenia - jego wyelidowanie prowadzi do osłabienia konstatacji, por. różnice w wynikach testów falsyfikacyjnych:

(26) ${ }^{*}$ Mówiąc o tym, co zagrał, że to jakiś inny motyw, mówię, że dobrze wiem, jaki to motyw. vs. Mówiąc o tym, co zagrał, że to inny motyw, mówię, że dobrze wiem, jaki to motyw.

(27) * Mówiąc o tym, co się za tym kryło, że to jakiś inny powód, mówię, że dobrze wiem, jaki to powód. vs. Mówiąc o tym, co się za tym kryło, że to inny powód, mówię, że dobrze wiem, jaki to powód.

Z punktu widzenia teorii jednostki języka ciąg jakiś inny p nie stanowi gotowej i niepodzielnej całości, o czym świadczy - poza dopuszczalną elipsą lewostronnego składnika - możliwość jego substytucji za pomocą innych elementów, np. operatorów gradacji, por.: całkiem inny motyw, zupełnie inny motyw, troche inny motyw, a nawet uzupełnienia nimi rozpatrywanego ciągu, np. jakiś zupełnie inny motyw, jakiś troche inny motyw. Można by także rozważać dostawienie do zaimka jakiś innego wyrażenia niż inny, ale choć połączenia tego typu są akceptowalne, pełnią inną funkcję niż rozpatrywane wyrażenie - są predykatywne, a nie referencjalne, por. np. Zagrał cichutko jakiś ładny motyw, Krył się za tym jakiś poważny powód, On ma jakiś dziwny adres mailowy. Ta właściwość nie osłabia jednak ustalenia, że badane wyrażenie należałoby uznać za złożenie jednostek, nie za odrębną jednostkę języka. 


\section{3. coś innego i nic innego}

Ciąg coś innego - jako człon nominalny - reaguje negatywnie zarówno na próbę prawostronnego uzupełnienia rzeczownikiem (por. dewiacyjne: ${ }^{\star}$ Przyjaźn to miało być coś innego uczucie), jak i na redukcję lewostronnego członu. Por. poniższe przykłady:

(28) Mnie jednak zastanawia coś innego / *Mnie jednak zastanawia innego.

(29) Ja pamiętam coś innego / *Ja pamiętam innego ${ }^{6}$.

(30) Przyjaźń to miało być coś innego / *Przyjaźń to miało być innego.

(31) Na Galapagos zdarzyło się coś innego / *Na Galapagos zdarzyło się innego.

(32) Ciągle się w coś innego przebierała, a jeszcze mówiła, że nie ma się w co ubrać / ${ }^{\star}$ Ciągle przebierała się w innego (...).

Wyniki prób usunięcia zaimka coś pokazują, że w przeciwieństwie do elementu inny z wyrażenia ktoś inny składnik inny z ciągu coś innego nie podlega substantywizacji. Zasadniczo można wprawdzie - podobnie jak w wypadku wyrażenia jakiś inny - próbować zastępować człon inny jakimiś innymi przymiotnikami, ale operacja taka przyczyni się do zmiany funkcji rozpatrywanego ciągu z referencjalnej na predykatywną (por. np. Ja pamiętam coś cudownego, Przyjaźń to miało być coś wyjątkowego, Na Galapagos zdarzyło się coś strasznego); świadczy o tym choćby brak rozważanej możliwości w wypadku przykładu (28) (w grę wchodzi tu ewentualnie substytucja dająca ciąg o postaci coś takiego).

Podobnie na redukcję lewostronnego członu reaguje formalnie nominalny ciąg nic innego, por. poniżej operacyjną modyfikację przykładów (33)-(37):

(33) Nie mając nic innego do roboty, poszedłem obejrzeć jarmark / *Nie mając innego do roboty, poszedłem obejrzeć jarmark.

(34) Marku, kocham cię i nic innego się dla mnie nie liczy / *Marku, kocham cię i innego się dla mnie nie liczy.

(35) Oprócz palenia i tak nic innego nie ma do roboty / *Oprócz palenia i tak innego nie ma do roboty.

(36) Co za prymityw! Na nic innego cię nie stać / *Co za prymityw! Na innego cię nie stać 7 .

(37) Możesz tylko rozbierać się i ubierać, nic innego nie pozostaje / *Możesz tylko rozbierać się i ubierać, innego nie pozostaje.

${ }^{6}$ Akceptowalne tylko w innym znaczeniu niż w wypowiedzeniu bazowym (tj. jako zsubstantywizowany przymiotnik będący składnikiem wyrażenia ktoś inny).

Por. wyżej przypis 6. 
Bardziej problematyczna natomiast jest kwestia faktycznej postaci tego wyrażenia. Wśród kontekstów z jego udziałem znajdujemy bowiem niejako dwa ich typy, por. przytoczone wyżej przykłady (33)-(37) z przykładami (38)-(42):

(38) Nie pozostaje mi nic innego, jak tylko się pożegnać.

(39) W oczach Ewy dostrzegł nic innego, tylko błękitny bezkres nieba.

(40) Bo zbawienie to nic innego jak kontynuacja stworzenia.

(41) Nie pozostawało mi jednak nic innego, jak podnieść ręce do góry.

(42) Natomiast sam cel to nic innego jak wielkie złudzenie.

Wydaje się, że we wszystkich wypowiedzeniach mamy do czynienia z jedną jednostką języka o pełnej postaci nic innego jak / tylko / niż. Chociaż bowiem ciąg nic innego z powodzeniem funkcjonuje bez uzupełnienia prawostronnego (por. (33)-(37)), to jest to w istocie różnica czysto powierzchniowa - w płaszczyźnie treści zawsze komunikuje się, że to, o czym mowa, dotyczy wszystkich elementów z wyłączeniem tego wskazanego. Explicite i w sposób kompletny wyraża się to w ramie z fraza jak_ (wariantywnie także: tylko / niż_) otwierającej miejsce dla bezokolicznika lub grupy nominalnej. Świadczy o tym to, że nawet konteksty, w których nic innego jest pozbawione rozpatrywanego prawostronnego uzupełnienia, można bez trudu przekształcić w struktury z tym elementem, por. np.:

(33’) Nie miałem nic innego do roboty, jak obejrzeć jarmark.

(34') Marku, nie liczy się dla mnie nic innego, jak tylko cię kochać.

(35') Nie ma nic innego do roboty, jak tylko palić / palenie.

(36’) Na nic innego go nie stać jak tylko na prymitywne zachowanie.

(37’) Nie pozostaje nic innego, jak rozbierać się i ubierać.

Podobnie rzecz się ma z rozważanym wcześniej wyrażeniem coś innego. Wśród autentycznych kontekstów również nie brakuje takich, w których jest ono prawostronnie uzupełnione frazą, tyle że z operatorem $n i \dot{z}_{-}$. Na takie struktury łatwo transformować przytoczone wcześniej przykłady ${ }^{8}$, por. np.:

(28’) Mnie jednak zastanawia coś innego niż to, o czym mówiłam wcześniej.

(29’) Ja pamiętam coś innego niż znane ci historie rodzinne.

8 Ze względów semantycznych takiemu przekształceniu nie podlega przykład (32) konstytuowany przez predykat ktoś przebiera się $w$ coś, por. dewiacyjne (bo redundantne): ${ }^{*}$ Ciagle przebierała się w coś innego, niż $w$ to, co miała na sobie wcześniej. Koniecznym warunkiem przebierania się jest bowiem ponowne ubieranie się w coś innego niż to, co miało się na sobie wcześniej. 
(30’) Przyjaźń to miało być coś innego niż to, co łączyło nas dawniej.

(31’) Na Galapagos zdarzyło się coś innego, niż wszystkim się wydawało.

Podsumowując, oba ciągi stanowią jednostki języka, tyle że ich pełna postać jest prawostronnie rozbudowana tak, że w oczywisty sposób wyklucza możliwość uzupełnienia rzeczownikiem (co jest możliwe w wypadku wyrażenia jakiś inny $p$ ). Bazowy element stanowi w obu rozważanych wyrażeniach nie składnik inny, lecz człon zaimkowy, do którego ewentualnie można redukować wyrażenie (ponosząc ryzyko zmiany lub niedostatecznie precyzyjnej jego referencji).

\section{4. nikt inny}

Ciąg nikt inny - jako że ma postać grupy imiennej - charakteryzuje się prawostronną blokadą dla rzeczownika (por. dewiacyjne połączenia *nikt inny nauczycielka, ${ }^{\star}$ nikt inny student). Lewostronny człon zaimkowy wprawdzie w niektórych kontekstach można zredukować, ale w wyniku takiej operacji powstają zdania albo nieakceptowalne (por. niżej (44) z ${ }^{\star} I n n y$, tylko ty!), albo różniące się od zdań wyjściowych ładunkiem poznawczym wynikającym z całkiem innej referencji przymiotnika inny (nawet zsubstantywizowanego) i wyrażenia nikt inny (por. niżej (43) z Innego nie chcę spotykać, tylko ciebie, (47) z Inny nie ruszył się z miejsca). Por.:

(43) Nikogo innego nie chcę spotykać, tylko ciebie.

(44) Nikt inny, tylko ty!

(45) Powiadam, że wrócę, bo nikt inny, tylko ja wydam Ewcię za mąż!

(46) Od dłuższego czasu poza nimi nie było nikogo innego na drodze.

(47) Nikt inny nie ruszył się z miejsca.

(48) Nikt inny nie woziłby mnie samochodem jak ze snu bulwarami Paryża.

W ISJP słowo inny w rozpatrywanym układzie uznano za wzmocnienie zaimka nikt lub nic (por. ISJP I, s. 538). Oczywiście, z racji tego, że to człon zaimkowy stanowi element bazowy rozpatrywanego ciągu, redukcja badanego wyrażenia do składnika nikt jest możliwa, ale bywa, że powoduje ona - choć w mniejszym stopniu niż elipsa zaimka - powstanie zdań różniących się referencją od zdań wyjściowych i prawdopodobnie względem nich nierównoznacznych (por. np. Nikt nie ruszył się z miejsca z przykładem (47)) $)^{9}$.

9 Por. ISJP I, s. 538: 'słowa inny używamy po zaimkach nikt i nic, aby je wzmocnić. Nikt inny przecież się o tym nie dowie... Nie pozostaje mi nic innego, jak tylko czekać. Gdyby rzeczywiście było tak, jak podaje ISJP, to elipsa członu inny nie wpływałaby ani na znaczenie, ani na odniesienie zdania wyjściowego. Tymczasem wypowiedzenie: Nikt przecież się o tym nie dowie nie jest równoważne $\mathrm{z}$ wypowiedzeniem Nikt inny przecież się o tym nie dowie. W drugim z nich mamy do czynienia ze 
Bardziej złożoną kwestią, rzutującą na podjęte rozważania, jest sprawa rzeczywistej, pełnej postaci jednostki językowej z udziałem tego ciągu. Wśród autentycznych kontekstów $\mathrm{z}$ tym wyrażeniem zarysowuje się bowiem pewne zróżnicowanie, ilustrują je z grubsza - wraz z wypowiedzeniami przytoczonymi powyżej - następujące przykłady:

(49) Od razu domyśliłam się, że tym panem nie może być nikt inny jak Toto.

(50) Jaką kobietą jest komendant w spódnicy? - Jest to nikt inny jak nauczycielka.

(51) Po wojnie, w roku 1946, nikt inny jak mój ojciec uruchamiał przedsiębiorstwo na nowo.

(52) Żołnierze umieją się zapomnieć jak nikt inny.

(53) Adam napisał, że zasłużył na nią jak nikt inny na świecie.

Wprawdzie w zdaniach (43)-(46) mamy do czynienia z uzupełnieniem wyrażenia nikt inny elementem tylko lub poza (wariantywnie także: oprócz), po którym następuje fraza nominalna, a w przykładach (47) i (48) analizowane wyrażenie występuje bez takiego uzupełnienia, ale w obu wypadkach w grę wchodzi taki sam mechanizm wyznaczania wyłączającego: wskazujemy jeden obiekt, wyłączając tym samym wszystkie pozostałe (por. przypis 9). Zatem w strukturze sensu rozpatrywane uzupełnienie jest elementem obligatoryjnym (por. przekształcone zdania (47) i (48):

Nikt inny poza tym, o którym mówię / którego mam na myśli / tobą, nie ruszył się z miejsca, Nikt inny poza tym, o którym mówię / którego mam na myśli / nim / tobą itp., nie woziłby mnie samochodem jak ze snu bulwarami Paryża).

Zasadne więc wydaje się uznanie rozpatrywanego wyrażenia ze zdań (43)-(48) za tę samą jednostkę języka i w związku z tym uwzględnienie w jej pełnym zapisie członu uzupełniającego: nikt inny, tylko_ / nikt inny poza_(oprócz_). Nie jest natomiast oczywiste potraktowanie jako wariantu tejże jednostki ciągu nikt inny uzupełnionego frazą z jak_w wypowiedzeniach (49)-(51). Chociaż bowiem zasadniczo możliwa jest substytucja elementu jak za pomocą tylko, co daje układy analogiczne do tych rozpatrywanych wyżej (por. (...) tym panem nie może być nikt inny tylko Toto, (...) nikt inny tylko mój ojciec uruchamiał przedsiębiorstwo na nowo), to jednak ta sama operacja w drugą stronę nie zawsze się udaje (por. nieakceptowalne substytucje rozpatrywanych wyrażeń z przykładów (43) i (44): ${ }^{*}$ Nikogo innego nie chce spotykać, jak ciebie, ${ }^{*}$ Nikt, jak ty!). Poza tym wyrażenie nikt inny jak_ wprowadza, jak się zdaje, trochę inną wartość leksykalną niż wyodrębniona wyżej jednostka z przykładów (43)-(48). Bez szczegółowej analizy

wskazaniem jednego obiektu i jednoczesnym wyłączeniem pozostałych, w pierwszym zaś - wyłącznie $\mathrm{z}$ wyłączeniem wszystkich elementów. Z punktu widzenia referencji mielibyśmy więc do czynienia z opozycją: referencja szczegółowa (określona) - referencja ogólna. 
trudno określić, czy chodzi o ładunek poznawczy (elementy treści), czy o warstwę sytuacyjno-wrażeniową (elementy użycia), czy może o współistnienie tych dwóch płaszczyzn. W każdym razie za pomocą tego wyrażenia mówi się chyba coś więcej niż w przykładach (43)-(48) w tym sensie, że o ile za pomocą jednostki nikt inny, tylko_ / nikt inny poza_ (oprócz_) faktycznie wyznaczamy jakiś obiekt, o tyle za pomocą ciągu nikt inny jak_ nie tylko go wyznaczamy, ale jeszcze - poprzez swoiste wyeksponowanie (jest to składnik inherentnie rematyczny) - wyróżniamy go na tle wszystkich pozostałych obiektów wchodzących w grę i tym samym obejmujemy go dodatkową charakterystyką, coś o nim orzekamy. Konteksty z tym wyrażeniem sprawiają wrażenie takich, które zapowiadają nam jakąś osobę, prezentują ją tak, jakby mówiący, wstawiając $\mathrm{w}$ tak przygotowaną ramę określone wyrażenie identyfikujące, szykował dla odbiorcy coś w rodzaju zaskoczenia czy niespodzianki. W związku z tym na obecnym etapie badań ciąg nikt inny jak_ uznaję za odrębną jednostkę języka, różną od nikt inny, tylko_ / nikt inny poza_ (oprócz_) i łączącą wyraźnie funkcję referencjalną z funkcją predykatywną.

Komentarza wymaga jeszcze wyrażenie nikt inny występujące w przykładach (52) i (53). W odróżnieniu od opisanych wyżej ciągów jest ono rozbudowane nie prawo-, a lewostronnie i stanowi niejako uzupełnienie czasownika. W tym wypadku nikt inny stanowi część konstrukcji zrobić coś jak_i jest elementem mogącym podlegać substytucji na inne, tworzone doraźnie i swobodnie, np. Żotnierze umieja się zapomnieć jak każdy, kto żyje w ciaglym stresie / studenci po sesji, Zasłużył na nia jak prymus na piątkę / laureat na nagrodę. Nie jest więc odrębną jednostką języka i nie jest też - co w kontekście charakteru tych badań warto podkreślić - wykładnikiem referencji, jako człon konstrukcji porównawczej pełni funkcję czysto predykatywną.

\section{5. żaden inny}

Ciąg żaden inny otwiera prawostronnie pozycję dla rzeczownika, należałoby zatem mówić o wyrażeniu o postaci żaden inny p (por. niżej przykłady (54)-(57)). Wspomniana pozycja zwykle jest wypełniona, choć możliwa jest, wynikająca zwykle z kontekstu zdania, elipsa członu nominalnego jak w przykładach (58)-(61) (por. niżej). Na tle pozostałych badanych wyrażeń ciąg żaden inny $p$ wyróżnia się stosunkowo dużą tolerancją na redukcję członu lewostronnego. W wyniku tej operacji zwykle powstają zdania pod względem znaczenia i referencji mniej więcej odpowiadające zdaniom wyjściowym. Ze względu na to, że w grę wchodzi referencja ogólna (dystrybutywna), w niektórych przykładach (zawierających rzeczowniki o odniesieniu osobowym) zasadne jest zmodyfikowanie formy rzeczownika występującego przy przymiotniku inny do liczby 
mnogiej oraz dostosowanie do niej form pozostałych składników konstrukcji. Por. niżej podane po ukośniku przykłady (54)-(57) będące rezultatami redukcji członu żaden:

(54) Żaden inny przemytnik żywego towaru nie mógł się z nim równać. / Inni przemytnicy żywego towaru nie mogli się z nim równać.

(55) Według policji w kolizji nie brał udziału żaden inny samochód. / Według policji w kolizji nie brał udziału inny samochód.

(56) Żaden inny kandydat nie ma tak zdyscyplinowanego elektoratu. / Inni kandydaci nie mają tak zdyscyplinowanego elektoratu.

(57) Nie miał żadnego innego planu. / Nie miał innego planu.

(58) Poczułam, że albo on, albo żaden inny.

(59) I tylko taki to był cel, żaden inny.

(60) Jeden z lokatorów stwierdził, że nie zamieniłby tego domu na żaden inny.

(61) Ten zawód ma jedną rzecz, której nie daje żaden inny.

Taki wynik przeprowadzonej operacji bierze się z tego, że inny $\mathrm{w}$ analizowanym wyrażeniu jest składnikiem głównym, a żaden stanowi element dodatkowy, który uściśla (czy też potwierdza ekspresywnie) zakres odniesienia przymiotnika inny. Treść komentarza z ISJP, dotyczącego wzmacniającej funkcji jednego z elementów wyrażeń nikt inny i nic innego (por. przypis 9), pasowałaby więc według mnie bardziej do ciągu żaden inny $p$ (tyle że funkcję tę przejmowałby w tym wypadku człon zaimkowy). Zdarza się jednak, że oderwanie zaimka żaden od członu głównego prowadzi do powstania wypowiedzeń budzących wątpliwości, por.:

(62) Żaden inny chłopak mnie nie pocałował.

(62') ?Inny chłopak mnie nie pocałował.

(63) Nie powiedziała tego żadnemu innemu mężczyźnie ${ }^{10}$.

(63’) ?Nie powiedziała tego innemu mężczyźnie.

(64) Żaden inny student tak się nie zachował.

(64') ?Inny student tak się nie zachował.

Przykłady (62'), (63’) i (64’) dałoby się pewnie bez większych zastrzeżeń zaakceptować jako wypowiedzi, a więc zdania użyte w określonym kontekście ${ }^{11}$, który

10 Zdania (63) i (64) są przykładami własnymi (spreparowanymi na potrzeby badań).

11 Przeciwstawiają się one zdaniom, powiedzmy, abstrakcyjnym, które sytuują się w planie langue, podczas gdy wypowiedź, jako faktyczna jednostka porozumiewania się, należy do planu parole. Na ten temat zob. np. Bachtin 1986, s. 365-366. 
uzupełnia elementy niezbędne do właściwego odniesienia wyrażenia. W przeciwnym razie należałoby uznać je za konstrukcje syntaktycznie niepełne, por. ich uzupełnione i akceptowalne warianty:

Inny chłopak, poza tym, o którym mówię, mnie nie pocałował, Nie powiedziała tego innemu mężczyźnie poza nim /, tylko jemu, Inny student, poza X-em, tak się nie zachował, Inny student tak się nie zachował, tylko X.

Tego typu przykłady zwracają uwagę na funkcję, jaką w rozpatrywanym ciągu pełni składnik żaden, a która polega na precyzowaniu przedmiotu odniesienia.

Rozpatrywana operacja redukcji wyrażenia do członu głównego jest niemożliwa w areferencjalnych (predykatywnych) ze swej natury konstrukcjach porównawczych z ciągiem żaden inny (nie: żaden inny p). W wyniku prostej redukcji lewostronnego składnika żaden otrzymujemy zdania niefortunne składniowo (por. niżej (65’) i (66’)), jeśliby je zaś odpowiednio pod tym względem skorygować, diametralnie różniłyby się znaczeniem od wypowiedzeń wyjściowych. Negacyjne właściwości zaimka żaden powodują, że jego wyelidowanie w rozważanych układach daje sądy semantycznie przeciwstawne (por. niżej (65”) i (66”). Por. wyniki opisanego testu:

(65) Temat aborcji dzieli Polaków jak żaden inny.

$\left(65\right.$ ’ ${ }^{\star T}$ Temat aborcji dzieli Polaków jak inny (temat).

(65”) Temat aborcji dzieli Polaków jak inne tematy.

(66) Jego rząd jak żaden inny pomaga samotnym matkom.

$\left(66^{\prime}\right)^{\star}$ Jego rząd jak inny pomaga samotnym matkom.

(66”) Jego rząd jak inne rządy pomaga samotnym matkom.

Mimo że konstrukcje porównawcze ze składnikiem żaden wyróżniają się na tle innych kontekstów z ciągiem żaden inny, nie reprezentują odrębnej jednostki języka. Jest to rodzaj dość swobodnie komponowanego złożenia: substytucji może podlegać zarówno składnik inny (np. jak żaden kolejny / następny / wcześniejszy / z pozostałych / z wymienionych), jak i człon żaden (np. jak wszystkie inne, jak każdy inny). Wprawdzie analogicznie na test substytucji członu głównego reaguje ciąg żaden inny p (por. żaden następny / kolejny / wcześniejszy / pozostały / wymieniony / dobry / madry p), ale operacja ta - podobnie jak w wypadku pozostałych analizowanych ciągów - powoduje zmianę funkcji wyrażenia z referencjalnej na predykatywną (por. np. żadna mądra kobieta, żaden dobry lekarz). Biorąc pod uwage fakt, że odrywalność członu żaden od głównego składnika inny - choć w wielu kontekstach możliwa (por. wyżej przykłady (54)-(57)) - miewa konsekwencje wpływające na akceptowalność wypowiedzeń, a także na skuteczność wyznaczania określonych elementów w rzeczywistości pozajęzykowej, trudno uznać 
rozpatrywane wyrażenie za złożenie, podobnie jak nie można przystać na uznanie stuprocentowej fakultatywności jego lewostronnego składnika. W związku z tym ciąg żaden inny p należałoby potraktować jako jednostkę języka.

3. Przeprowadzone badania pozwalają na przyjęcie następujących ustaleń.

1) Spośród sześciu wziętych pod uwagę ciągów aż pięć można uznać za jednostki języka, przy czym pełna postać większości z nich jest bardziej rozbudowana niż wyjściowe, hipotetyczne dwuelementowe wyrażenia (w tym jeden z nich konstytuuje dwie różne jednostki). Należą do nich: ktoś inny, coś innego niż_, nic innego jak_(tylko / niż_), nikt inny, tylko_/ poza_(oprócz_), nikt inny jak_i żaden inny p; ciąg jakiś inny p uznałam za złożenie (złożony operator). Warto zaznaczyć, że nie wyczerpują one listy, która mogłaby realizować serię o umownej postaci _inny, bo można by ją uzupełnić jeszcze o inne wyrażenia, np. każdy inny, wszyscy inni.

2) Pełna postać wyodrębnionych jednostek języka pokazuje względne zróżnicowanie rozpatrywanych wyrażeń. Większość z nich zawiera dodatkowe elementy precyzujące zakres odniesienia, realizowane (nie zawsze powierzchniowo) poprzez frazy z operatorami jak_, niż_, tylko_,poza_. Różni je zasadniczo sprawa blokady lub otwierania pozycji prawostronnej dla rzeczownika (dwa badane ciągi mają postać grupy nominalnej: jakiś inny p i żaden inny p), natomiast rozważany problem odrywalności lewostronnego członu raczej je łączy, niż dzieli - wszystkie, poza wyrażeniem jakiś inny p, źle reagują na redukcję składnika zaimkowego: albo jej nie dopuszczają (por. coś innego niż, nic innego jak_(tylko / niż_), nikt inny, tylko_/ poza_(oprócz_), nikt inny jak_), albo jest ona możliwa pod określonymi warunkami (ktoś inny, żaden inny p).

3) Mniej decydująca w prowadzonej analizie okazała się sprawa substytucji obu składników badanych ciągów: substytucja pierwszego z nich w zasadzie rozbudowuje badaną serię wyrażeń (por. np. każdy inny, wszyscy inni), substytucja drugiego z nich prowadzi do dość regularnego zjawiska polegającego na zmianie funkcji wyrażenia $\mathrm{z}$ referencjalnej na predykatywną. Rzecz wydaje się jednak bardziej złożona. Jak pokazuje A. Bogusławski w swoim tekście z 1977 r., wśród wyrażeń o właściwościach indeksowych są i indeksy, i czyste indeksy, i takie wykładniki referencji, które mają cechy dictum (por. Bogusławski 1977). Obecność elementów zaimkowych, nawet dostawionych do innych wyrażeń niż przymiotniki indeksujące, nie pozbawia chyba takich ciągów właściwości indeksowych. Inna sprawa, że są to wówczas na pewno doraźne zestawienia, funkcjonalnie różne od wybranych do zbadania kandydatów na jednostki języka, por. np.

ktoś lepszy, ktoś zdolny, ktoś bogaty, jakiś ładny motyw, jakiś poważny powód, coś cudownego, cośstrasznego, coś wyjątkowego, nic lepszego, nic ciekawego, nic ważnego, nikt madry, nikt rozsądny, żaden dobry lekarz, żadna madra kobieta. 
4) Problem zasygnalizowany wyżej wiąże się z kolejnym, widocznym w próbie porównania zdań z badanymi wyrażeniami $w$ ich pełnej postaci ze zdaniami, w których badane ciągi zostały pozbawione członu zaimkowego. Chodzi mianowicie o takie wypadki, w których operacja ta zasadniczo nie wpływa na akceptowalność wypowiedzeń i nie rzutuje znacząco na wartość informacyjną zdań (por. przykłady (18)-(25) z jakiś inny p i (54)-(57) z żaden inny p). To jednak dość ostrożna i zachowawcza charakterystyka, bo nic definitywnie nie rozstrzygając, dopuszcza jednak możliwość jakiejś zmiany rzutującej na interpretację wypowiedzeń (do której zresztą dochodzi, por. (26), (27), (62’), (63’) i (64’)). Pytanie podstawowe sprowadza się do rozstrzygnięcia, czy możliwa zmiana (np. jakiś inny $p$ vs inny $p$, żaden inny $p$ vs inny $p+n e g$.$) wynika z różnicy znaczeń,$ czy z różnicy referencji. W wypadku ciągu jakiś inny $p$ dotyczy ona, jak pokazują sprzeczne przykłady (26) i (27), płaszczyzny treści, natomiast w ciągu żaden inny $p$ - prawdopodobnie cech odniesienia (por. taki sam wynik testu falsyfikacyjnego w zdaniach:

*Żaden inny kandydat nie nadaje się na to stanowisko, ale jest jeszcze jeden kandydat, który nadaje się na to stanowisko, ${ }^{*}$ Inny kandydat nie nadaje się na to stanowisko, ale jest jeszcze jeden kandydat, który nadaje się na to stanowisko).

Problem wymaga jednak szczegółowych analiz, uwzględniających także explicite zdanie sprawy z tego, na czym miałaby polegać „funkcja wzmacniająca” elementów takich jak żaden czy inny w wyrażeniach (odpowiednio): żaden inny $p$, nikt inny jak_, nikt inny, tylko_ / poza_(oprócz_) i nic innego jak / tylko / niż (jeśli weźmie się pod uwagę ich pełną postać, redukcja elementów, które miałyby pełnić tę funkcję bywa niemożliwa, por. Jaką kobietą jest komendant w spódnicy? - ${ }^{\star}$ Jest to nikt jak nauczycielka, ${ }^{*}$ Nikt jak mój ojciec uruchamiał przedsiębiorstwo na nowo). Istotne jest to, czy rzutuje ona na precyzyjność operacji wyznaczania (identyfikowania), czy też tworzy coś w rodzaju, powiedzmy, aury wyrażenia, a więc dotyczy aktualnych okoliczności sytuacyjnych wpisujących się we właściwości pragmatyczne. Wydaje się, że dominować może jednak pierwsza z wymienionych funkcji.

Przechodząc do ostatecznego podsumowania, należy stwierdzić, że przedmiotem analizy były byty językowe różne na tyle, że moje wcześniejsze próby sprowadzenia ich opisu do wspólnego mianownika były pochopne i nieuzasadnione. Są to w większości odrębne całości językowe wyposażone w indywidualne cechy, łączy je natomiast (poza podobieństwem powierzchniowym wynikającym z obecności w ich składzie słowa inny) to, że pełnią funkcję wykładników referencji. 


\title{
Bibliografia
}

Bachtin, M. (1986). Estetyka twórczości słownej. Warszawa.

Bogusławski, A. (1976). O zasadach rejestracji jednostek języka, Poradnik Językowy 8, 356-364.

Bogusławski, A. (1977). O interpretacji zdań z wyrażeniami okazjonalnymi, Przeglą Humanistyczny 2, 39-56.

Bogusławski, A., Wawrzyńczyk, J. (1993). Polszczyzna, jaką znamy. Nowa sonda słownikowa. Warszawa.

ISJP - Inny słownik języka polskiego, (red.). M. Bańko, t. I-II. Warszawa 2000.

Jodłowski, S. (1971). Studia nad częściami mowy. Warszawa.

NKJP - Narodowy Korpus Języka Polskiego, [on-line:] nkjp.pl

Topolińska, Z. (1984). Składnia grupy imiennej. W: Gramatyka współczesnego języka polskiego. Składnia, red. Z. Topolińska. Warszawa, 301-386.

Wołk, M. (2019). Inny, różny, odrębny, odmienny. Próba wyodrębnienia jednostek języka, Poradnik Językowy 9, 50-65.

\begin{abstract}
ABSTRAKT: Przedmiotem badań w niniejszym artykule jest seria wyrażeń zbudowanych z przymiotnika inny i lewostronnie dostawionego do niego zaimka. Obok tytułowego wyrażenia należą do niej takie ciągi, jak np. nikt inny, żaden inny, jakiś inny, coś innego, nic innego. Celem podjętych rozważań jest ustalenie statusu wyrażeń, które na pierwszy rzut oka wpisują się w dość jednolitą serię. Sprawą podstawową jest rozstrzygnięcie, czy są one odrębnymi jednostkami języka (w rozumieniu Andrzeja Bogusławskiego (1976)), czy regularnymi złożeniami. Dojście do takich ustaleń wymaga indywidualnego potraktowania każdego z sześciu wybranych do analizy wyrażeń. Podstawowym testem służącym do zbadania postawionego problemu jest test redukcji członu lewostronnego. Drugą rzeczą braną pod uwagę w badaniach jest kwestia otwierania vs blokowania prawostronnej pozycji dla rzeczownika. Dodatkowo uwzględniono test substytucji członów składających się na opisywane ciągi. Artykuł stanowi próbę rewizji jednej z wcześniej wysuniętych przeze mnie dość pochopnie hipotez dotyczących statusu rozpatrywanych wyrażeń.
\end{abstract}

